\title{
Does neuromuscular exercise training improve proprioception in ankle lateral ligament injury among athletes? Systematic review and meta-analysis
}

\author{
O treinamento neuromuscular melhora a propriocepção em lesão ligamentar lateral \\ do tornozelo entre atletas? Revisão sistemática e metanálise
}

\author{
Deivendran Kalirathinam ${ }^{1} \bowtie$, Mohamed Saat Ismail2, Taran Singh Pall Singh ${ }^{3}$, \\ Soumendra Saha², Hairul Anuar Hashim² \\ ${ }^{1}$ Universiti Sultan Zainal Abidin, Faculty of Health Sciences. Kuala Terengganu, Terengganu, Malaysia. \\ 2 Universiti Sains Malaysia, School of Health Sciences, Exercise \& Sport Science Program. Kubang Kerian, Kelantan, Malaysia. \\ 3 Universiti Sains Malaysia, School of Medical Sciences, Department of Orthopedics. Kubang Kerian, Kelantan, Malaysia.
}

\section{ABSTRACT}

Aims: The prevalence rate of ankle complexities is increasing at a constant rate among athletes. This study aimed to systematically describe the facts and findings related to the effectiveness of training programs on proprioception among athletes suffering from ankle ligament injury. Methods: A literature search in online libraries (Google Scholar, PubMed, EBSCOhost, and ProQuest) using different search engines was conducted for the systematic review and meta-analysis. The common keywords included NEUROMUSCULAR, EXERCISE, TRAINING, PROPRIOCEPTION, and ATHLETES. Studies related to the topic, having relevant resources, and published within the past 10 years were used as inclusion criteria. Methodological quality was assessed through PEDro scale. A meta-analysis of the selected trials was conducted to assess the effectiveness of intervention.

Results: Two hundred research articles were initially selected. After close scrutiny, 15 articles were included. Five moderate to excellent quality trials were selected, which involved 2,459 participants. It has been mainly identified that ankle sprain and its complications can be easily prevented with the help of training programs (five trials, relative risk: $0.69,96 \% \mathrm{CI}$ : $0.65-0.87$ ). A statistically significant relationship was identified among athletes regarding the preventive impacts of training on proprioception.

Conclusions: Preventive training programs were helpful for athletes in terms of proprioception, thus reducing the risk of ankle sprains.

KEY WORDS: ankle; athletes; athletic injuries; ligament injury; proprioception; physical education and training.

\section{RESUMO}

Objetivos: A taxa de prevalência de lesões no complexo ligamentar lateral vem aumentando entre os atletas a uma velocidade constante. Este estudo teve por objetivo descrever sistematicamente os achados relacionados à eficácia dos programas de treinamento na propriocepção entre atletas com lesão ligamentar do tornozelo.

Métodos: Foi realizada uma busca em bases de dados online (Google Scholar, PubMed, EBSCOhost e ProQuest) com o uso de diferentes mecanismos de busca, para revisão sistemática e metanálise. Os descritores comuns foram NEUROMUSCULAR, EXERCISE, TRAINING, PROPRIOCEPTION, and ATHLETES. Os estudos relacionados ao assunto, os que continham recursos relevantes e aqueles publicados nos últimos 10 anos foram usados como critério de inclusão. A qualidade metodológica foi avaliada pela escala PEDro. Foi feita uma metanálise dos estudos selecionados a fim de avaliar a eficácia da intervenção.

Resultados: Inicialmente, foram selecionados 200 artigos de pesquisa. Após uma avaliação detalhada, restaram 15 artigos. Cinco estudos de qualidade moderada a excelente foram selecionados, totalizando 2.459 participantes. Verificou-se, principalmente, que o entorse de tornozelo e suas complicações podem ser evitados facilmente com o auxílio de programas de treinamento (cinco estudos, risco relativo: 0,69, IC 96\%: 0,65-0,87). Observou-se uma relação estatisticamente significativa em termos dos efeitos preventivos do treinamento na propriocepção entre atletas.

Conclusões: Os programas de treinamento preventivos foram úteis aos atletas em termos de propriocepção, reduzindo o risco de entorses de tornozelo.

DESCRITORES: tornozelo; atletas; traumatismos em atletas; lesão ligamentar; propriocepção; educação física e treinamento. 
Abbreviations: RR, relative risk; NNT number needed to treat.

\section{INTRODUCTION}

The prevalence of ankle injuries is extremely common in a wide variety of sports and athletics. Athletes who suffer ankle sprains are prone to reinjure the same ankle, which usually results in disability and chronic instability. Among all sports, volleyball has a relatively higher incidence of ankle injuries [1]. Several balance exercises and other neuromuscular training have been arranged in order to reduce the clinical manifestations of ankle injuries. Exerciserelated training programs are aimed to increase neuromuscular strength, which is required for resistance against the destabilizing load on the knee [2]. It is well documented that female athletes are comparatively at higher risk of acquiring knee injuries as compared to male athletes [3]. Therefore, most of the training programs are designed to reduce the risk of injuries and their complications among female individuals. Future complications of knee injuries have a direct impact on athletes' quality of life [4]. Similarly, knee ligament injuries are widely associated with chronic pain which, in turn, results in long-term disability. Tendons and ligaments are systematic parts of the neuromuscular system that require certain dietary supplements and training programs for enhancement of energy levels. Therefore, athletes are always recommended to enhance their energy levels by means of exercise training programs.

Osteoarthritis has now been considered the second most common morbidity among older adults. Moreover, this diagnosis has been identified as a major contributing factor to the increase in the risk of disability in senior individuals [5]. Along with the older population, athletes have been also identified as individuals at risk for acquiring such complications [6]. For patients with knee disability, total knee replacement is considered a major surgical approach to effectively addressing the complications [7]. According to the most recent meta-analysis, preoperative exercises play a vital role in functional recovery. Some of the common exercises identified as the best intervention against the complications of osteopathy include mainly aerobics, proprioceptive exercises, and strength exercises [8,9]. An appropriate exercise program is an important way to assess and address deficiencies in the human body $[10,11]$. Therefore, exercises have been identified as an effective therapeutic intervention for the morbid complications of osteoarthritis or ankle injuries.

Proprioception and its clarification have different meanings in diverse regions. In early years, proprioception was defined as the ability to receive input from tendons, joints, and muscles through proper functioning of the central nervous system. This definition of proprioception, however, was not acceptable across different countries. Therefore, controversies continued to prevail over universally accepted definitions of proprioception. Since 1906, many definitions of proprioception have been formulated on the basis of different facts. Currently, neurophysiologists have defined proprioception as the input that occurs due to stimuli in three locations, which include peripheral mechanoreceptors, the visual system, and the vestibular system [12]. Shifting et al. [13] have suggested the significant functional capabilities of proprioceptive training exercises for reducing the risk of ankle sprains in the sporting population. There are reports that ankle sprains are extremely common consequences of sports-related injuries, being frequently associated with ankle replacement or disability $[14,15]$.

High prevalence of ankle sprains is associated with directional changes, jumping activities, and pivoting $[16,17]$. Ankle tendon dysfunction, disability and pain, and economic burden have been commonly seen when assessing such complications. Chronic instability and impairment have been also diagnosed in athletes with ankle sprains [18]. For that purpose, proprioception has been identified as a complex neuromuscular process, which is concerned with kinesthetic awareness of body movement and body positioning. Efferent signaling and afferent responses play a significant role in injury prevention and joint stability [19]. Proprioceptive training exercises have been targeted to detect and improve joint position. Systematic reviews have explored proprioceptive exercises for the prevention and management of ankle sprains among athletes [20,22]. Strengthening, proprioceptive training, plyometric training, agility, and the combination of such neuromuscular interventions have been identified as rehabilitation measures. A systematic review also found effectiveness of functional rehabilitation interventions, evaluated by functional assessment tools, in improving athlete strains in accordance with their symptoms and complications [23].

Verhagen et al. [24] have demonstrated that proprioceptive balance training is a valuable effective approach for the prevention of ankle sprains in volleyball players. This approach is widely used in 
rehabilitation centers, in order to restore damaged structures and ligaments around the ankle. Such training programs are also considered an effective alternative to bracing or taping for the prevention of sprains. Holm et al. [3] mention that side-to-side differences between limbs are usually expressed by the limb symmetry index. This approach is useful in training programs for assessing the value and frequency of functional deficit. Neuromuscular training programs were also introduced for handball teams because a study showed the risk of anterior cruciate ligament rupture among handball players [3].

Therefore, it can be said that neuromuscular training programs are widely used in the athletic domain in order to reduce the risk of severe complications of anklerelated injuries. Based on such facts, this systematic review aimed to analyze the effects of neuromuscular training programs on proprioception among athletes.

\section{METHODS}

A mixed research design was implemented for data collection and interpretation. The rationale behind the selection of this design was to gather authentic and relevant data for a systematic review and metaanalysis. Moreover, the mixed research design is also an authentic and widely recognized format in innovative research. Similarly, the mixed research design has also been effective for collecting a wider range of data for identification of the best outcome. Therefore, it is said that the mixed research design helps explore proprioception in neuromuscular training programs [37].

An appropriate search in the published literature using online libraries (Google Scholar, PubMed, EBSCOhost, and ProQuest) and different search engines was carried out. Keywords included NEUROMUSCULAR, EXERCISE, TRAINING, PROPRIOCEPTION, and ATHLETES. The inclusion criteria consisted mainly of studies related to the topic, having relevant resources, and published in the past 10 years.

The articles were scrutinized on the basis of relevance to the topic, abstract quality, knowledge level, quality of information, and authentication of resources. The initially selected 15 articles were further scrutinized by associated experts, resulting in the selection of the five best research articles for the systematic review and meta-analysis. Relevance and updated resources were two major aspects of the selection criteria. This process helped investigators enhance the quality of research articles in an effective way.
The collected data were analyzed by means of a systematic review and meta-analysis. After data collection, the research articles were evaluated on the basis of research questions. Relevant and necessary information was obtained from the selected articles in order to answer the research questions. The statistical analysis was conducted using IBM SPSS, version 20.

\section{RESULTS}

Initially, 200 research articles were selected for analysis, but this number dropped to 15 after the scrutiny process. The electronic search in the database yielded 200 research studies after removal of duplicate articles. Out of such extensive database collection, 15 research articles underwent full-text review. Ten of these were excluded from the research process for different reasons. The first one was that the studies were not randomized controlled trials. Another reason was that the control groups were also receiving neuromuscular training similar to the training groups. The remaining five research studies were included for the final analysis (Figure 1).

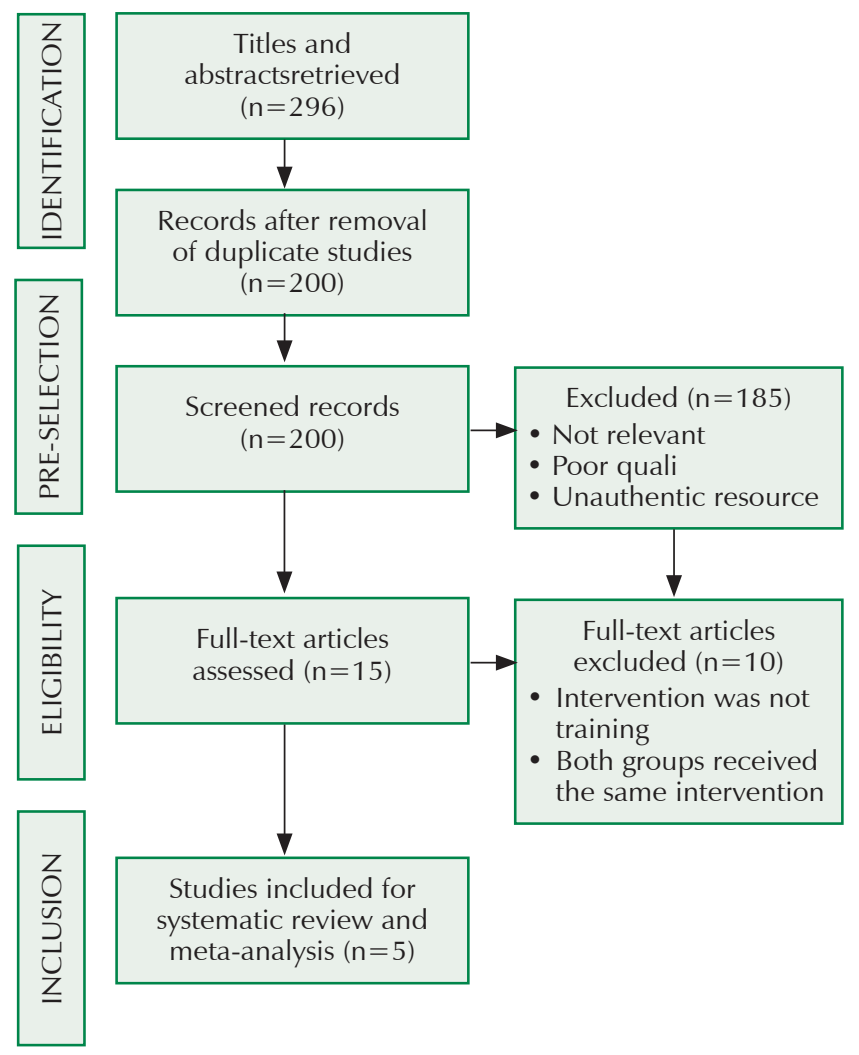

Figure 1. Selection of studies on the effectiveness of proprioceptive training programs among athletes suffering from ankle ligament injury. 
These five research studies comprised 2,459 participants. Table 1 shows the complete details about the included studies. PEDro scores of the selected studies ranged from 3 to 6 with an average score of 4.4/10. Using a grading system for PEDro scores, two of the selected five articles were identified as having "excellent quality" (score around 5 or 6), two were considered to be of "good quality" (score 3 or 4), and one study was of "moderate quality" (score 2). The five selected trials were identified to be homogenous from a statistical point of view. A meta-analysis of the five selected trials was performed, which revealed a statistically significant reduction in the extent of ankle injuries during proprioceptive training programs (5 trials, relative risk $[R R]=0.69,96 \% \mathrm{CI}$ : 0.65-0.87). Such findings represented the number needed to treat (NNT) of $17(96 \% \mathrm{CI}: 0.65-0.87)$, indicating that around 17 athletes would require proprioceptive training in order to prevent ankle injuries or its complications.

Comparison interventions included warm-up routines, usual care, and strength training. When such results were subdivided for analyzing the secondary effects of proprioceptive training programs, the outcomes were mainly related to the intervention (four trials, $\mathrm{RR}=0.54,94 \% \mathrm{CI}: 0.56-0.85 ; \mathrm{NNT}=12,93 \% \mathrm{CI}$ : 99-6). While assessing the effect of proprioceptive training among athletes without any related history of ankle injuries, the pooled outcomes were statistically significant $(\mathrm{RR}=0.56,94 \% \mathrm{CI}: 0.38-0.95 ; \mathrm{NNT}=35$, 93\% CI:1000-13). The confidence interval was also analyzed, showing larger differences (Figure 2).

Table 1. Details of the interventions, outcomes, participants, and quality score of the studies that assessed effectiveness of proprioceptive training programs among athletes suffering from ankle ligament injury.

\begin{tabular}{|c|c|c|c|c|c|c|c|c|}
\hline \multicolumn{2}{|c|}{ Study Details } & \multicolumn{2}{|l|}{ Participants } & \multicolumn{4}{|c|}{ Intervention } & \multirow{2}{*}{$\begin{array}{l}\text { Outcomes } \\
\text { Follow-up }\end{array}$} \\
\hline Study & Quality & Characteristics & $\mathbf{n}$ & Intervention & Frequency & Duration & Control & \\
\hline $\begin{array}{l}\text { Hupperets et al. } \\
\text { (2009) [25] }\end{array}$ & $\begin{array}{c}\text { Excellent } \\
(\text { PEDro = 6) }\end{array}$ & $\begin{array}{l}\text { Male and female } \\
\text { athletes with percentile } \\
\text { of } 52 \% \text { and } 48 \% \text {, } \\
\text { respectively, were } \\
\text { selected, with ankle } \\
\text { sprain for around } 2 \\
\text { months. }\end{array}$ & 522 & $\begin{array}{l}\text { Usual care was given } \\
\text { immediately after the } \\
\text { injury. In addition, } \\
\text { proprioceptive training } \\
\text { programs were also } \\
\text { arranged. }\end{array}$ & $\begin{array}{c}\text { 30-minutes } \\
\text { session, } 3 \text { times } \\
\text { a week. }\end{array}$ & 8 weeks & $\begin{array}{c}\text { Usual care after } \\
\text { injury }\end{array}$ & $\begin{array}{l}\text { One } \\
\text { complete } \\
\text { year }\end{array}$ \\
\hline $\begin{array}{l}\text { Emery et al. } \\
\text { (2007) [26] }\end{array}$ & $\begin{array}{c}\text { Excellent } \\
(\text { PEDro = 5) }\end{array}$ & $\begin{array}{l}50 \% \text { of male and } \\
\text { female athletes, } \\
\text { specifically basketball } \\
\text { players, with ankle } \\
\text { lateral ligament injury, } \\
\text { were selected. }\end{array}$ & 920 & $\begin{array}{l}\text { Specific sport balance } \\
\text { training programs were } \\
\text { arranged along with } \\
\text { home-based training } \\
\text { programs through } \\
\text { wobble board. }\end{array}$ & $\begin{array}{c}\text { Around } \\
5 \text { minutes for } \\
\text { each practice } \\
\text { session. } \\
20 \text { minutes for } \\
\text { home training. }\end{array}$ & 18 weeks & $\begin{array}{l}\text { Warm-up } \\
\text { programs } \\
\text { as per the } \\
\text { standards }\end{array}$ & 18 weeks. \\
\hline $\begin{array}{l}\text { Mohammadi } \\
\text { (2007) [27] }\end{array}$ & $\begin{array}{c}\text { Good } \\
(\text { PEDro }=4)\end{array}$ & $\begin{array}{l}\text { Professional soccer } \\
\text { players with mean age } \\
\text { of } 25 \text { years and past } \\
\text { history of ankle sprain } \\
\text { were selected. }\end{array}$ & 80 & $\begin{array}{l}\text { Home-based } \\
\text { proprioceptive training } \\
\text { programs were } \\
\text { arranged. }\end{array}$ & $\begin{array}{l}\text { Around } \\
30 \text { minutes } \\
\text { every day }\end{array}$ & $\begin{array}{c}120 \\
\text { sessions }\end{array}$ & $\begin{array}{l}\text { Ankle } \\
\text { evertor strength } \\
\text { training }\end{array}$ & $\begin{array}{l}\text { Conclusion } \\
\text { of the entire } \\
\text { season. }\end{array}$ \\
\hline $\begin{array}{l}\text { McGuine \& Keene } \\
\text { (2006) [28] }\end{array}$ & $\begin{array}{c}\text { Good } \\
(\text { PEDro = 3) }\end{array}$ & $\begin{array}{l}68 \% \text { of female and } \\
32 \% \text { of male basketball } \\
\text { and soccer players } \\
\text { were selected. } 76 \% \\
\text { of participants did not } \\
\text { have any history of } \\
\text { ankle sprain; however, } \\
24 \% \text { did. }\end{array}$ & 765 & $\begin{array}{l}\text { 5-phase balance } \\
\text { training programs } \\
\text { were developed by } \\
\text { using single leg stance } \\
\text { exercises. }\end{array}$ & $\begin{array}{l}5 \times 5 \text { training } \\
\text { session for } \\
4 \text { weeks }\end{array}$ & 4 weeks & $\begin{array}{l}\text { Conditioning } \\
\text { exercises } \\
\text { under training } \\
\text { programs }\end{array}$ & $\begin{array}{c}\text { Exact duration } \\
\text { was not } \\
\text { mentioned }\end{array}$ \\
\hline $\begin{array}{l}\text { Eils et al. } \\
\text { (2010) [2] }\end{array}$ & $\begin{array}{l}\text { Moderate } \\
(\text { PEDro = 2) }\end{array}$ & $\begin{array}{l}\text { Professional basketball } \\
\text { players, with past } \\
\text { medical history of } \\
\text { ankle sprain were } \\
\text { selected. }\end{array}$ & 172 & $\begin{array}{l}\text { Multistation } \\
\text { proprioceptive training } \\
\text { programs were } \\
\text { arranged. }\end{array}$ & $\begin{array}{l}\text { Once a week } \\
\text { for around } \\
20 \text { minutes. }\end{array}$ & $\begin{array}{l}\text { One specific } \\
\text { season } \\
\text { (duration } \\
\text { undefined) }\end{array}$ & $\begin{array}{c}\text { Standard } \\
\text { workout only }\end{array}$ & $\begin{array}{l}\text { Unspecific } \\
\text { duration. }\end{array}$ \\
\hline
\end{tabular}




\begin{tabular}{|c|c|c|c|c|c|c|c|}
\hline \multirow[b]{2}{*}{ Study or Subgroup } & \multicolumn{2}{|c|}{ Proprioception } & \multicolumn{3}{|c|}{ Control } & \multirow{2}{*}{$\begin{array}{c}\text { Risk Ratio } \\
\begin{array}{c}\text { M-H, Random, } \\
\text { 95\%Cl }\end{array}\end{array}$} & \multirow{2}{*}{$\begin{array}{c}\text { Risk Ratio } \\
\mathrm{M}-\mathrm{H}, \text { Random, } 95 \% \mathrm{Cl}\end{array}$} \\
\hline & Events & Total & Events & Total & Weight & & \\
\hline Mohammadi, 2007 & 1 & 19 & 15 & 54 & $0.5 \%$ & $0.25[0.04,1.58]$ & \multirow[t]{6}{*}{$\longleftarrow$} \\
\hline Elis et al. 2010 & 11 & 52 & 21 & 54 & $7.5 \%$ & $0.45[0.24,0.96]$ & \\
\hline McGuine \& Keene, 2006 & 21 & 389 & 36 & 381 & $10.01 \%$ & $0.51[0.14,0.78]$ & \\
\hline Hupperetes et al. 2009 & 58 & 254 & 79 & 267 & $32.7 \%$ & $0.67[0.47,0.78]$ & \\
\hline Emery et al. 2007 & 60 & 495 & 74 & 461 & $27.54 \%$ & $0.60[0.42,0.86]$ & \\
\hline Total $(95 \% \mathrm{Cl})$ & & 1986 & & 1587 & $100 \%$ & $0.65[0.45,0.87]$ & \\
\hline Total events & 194 & & 293 & & & & \\
\hline \multicolumn{7}{|c|}{ Heterogeneity: $\mathrm{Tau}^{2}=0.00 ; \mathrm{Chi}^{2}=5.70, \mathrm{df}=6(\mathrm{P}=0.46) ; \mathrm{I}^{2}=0 \%$} & \multirow[t]{2}{*}{$\begin{array}{ccccccc}0.1 & 0.2 & 0.5 & 1 & 2 & 5 & 10 \\
\text { Favors [proprioception] Favors [control] }\end{array}$} \\
\hline \multicolumn{7}{|c|}{ Test for overall effect; $\mathrm{Z}=5.02(\mathrm{P}<0.00001)$} & \\
\hline
\end{tabular}

Figure 2. Meta-analysis of the studies on the effectiveness of proprioceptive training programs among athletes suffering from ankle ligament injury.

\section{DISCUSSION}

The overall findings of the meta-analysis and systematic review indicated that there was a direct impact of neuromuscular training programs on proprioception, preventing and reducing the risk of chronic complications. The findings also indicated that ankle injury and sport were two independent variables as there was not a major impact of these variables on health or training programs. As suggested by the systematic review and the meta-analysis, all of the five studies supported the implementation of proprioceptive neuromuscular training programs [2,25-28]. In order to develop a supportive argument for the implication of neuromuscular training programs, the study utilized a wider range of qualitative and quantitative studies. The rationale behind this approach was to specify the attained outcomes with the previous literature on the basis of authenticity and review.

Bazzucchi et al. [29] focused on the significance of training exercises concerning neuromuscular complications among diabetes mellitus patients. Diabetes mellitus is directly associated with the development of severe disability; therefore, the trends and significance related to neuromuscular training exercises can be easily witnessed. The study mentioned that deleterious changes usually occur in muscle contractile properties and motor nerves, often reducing muscle strength and power. Therefore, regular neuromuscular exercises are beneficial as they reduce the risk of morbidities. Similarly, Ageberg and Roos [30] identified that neuromuscular exercise training can be easily used as significant treatment for degenerative diseases. Degenerative diseases usually affect the muscular system, specifically among women. The outcomes specifically depict that knee problems resolve after neuromuscular exercise training for a specified time frame. A randomized controlled trial was conducted by Villadsen et al. [31], demonstrating beneficial results of neuromuscular exercises after hip and knee arthroplasty. The trial also mentions that neuromuscular exercises are beneficial for tendons and muscles during strains. Although the three selected studies have no relationship with athletics and sports, they strongly support the importance of neuromuscular exercises for morbidities related to the muscular system. Therefore, it can be said that neuromuscular exercise training programs help patients avoid pain and other complications associated with the muscular system.

Proprioceptive training programs for prevention of pain and strains is another valuable aspect. Many outcomes have been identified through systematic reviews and meta-analyses. However, the previously published literature also supports the statistical relationship between prevention and proprioception. A randomized controlled trial was conducted [28], which focused on participants with no history of ankle sprains. This trial did not show any impact of training programs on proprioception as regards prevention. However, the meta-analysis showed a statistically significant pooled impact after comparison with those participants with a history of ankle sprains [28]. A research study selected those individuals or athletes with a prior history of ankle sprains. The results show a positive impact of training programs on proprioception [2]. Similarly, compliance levels are directly associated with the impact of training programs on proprioception 
regarding the prevention of ankle injuries. There was variability among different research studies; however, the level of compliance plays a major role in experimental settings in so that the best outcomes can be achieved [17]. At the same time, the effectiveness of proprioceptive training to treat ankle injury among athletes suggests that rehabilitative effects have been analyzed because of a proper mechanism. It has been ideally proposed that such training programs help patients address their impairments and fight the complications of ankle injury. A past research study supported that neuromuscular training programs help athletes effectively reduce the risk of acquiring severe chronic complications [32].

Because of the remarkable similarities between the clinical perspective and the selected research studies, it can be said that the findings of this research study can be also applied in the clinical environment. The selected research studies utilized the best possible clinical approaches, which may help clinicians improve their practices in an effective way. Therefore, it can be said that the clinical application of all these outcomes is possible due to the appropriate level of impact on preventive approaches [2,25-28].

As clinical approaches are effective, proprioceptive training programs significantly help athletes assure their well-being and wellness regarding ankle strains and disability. In addition, athletes are also exposed to disability risk, which is mostly reduced through trainings. Moreover, proprioceptive training exercises are mostly broken into different sessions, which are necessary for organization and promotion of wellness in accordance with the human body [2,28]. Therefore, it can be said that training programs and exercises must be arranged through effective strategies to avoid any potential risk of ankle injuries.

The study also demonstrates that training programs that include vigorous exercises are not as effective as functional exercises in reducing the risks and complications of ankle strains. Proprioceptive and neuromuscular exercises substantially help athletes to prevent the risk of such complications for their normal osteopathic and physiological functioning [17]. Similar outcomes were retrieved by the current study in order to assess the compliance level. Therefore, it is said that proprioceptive training programs greatly help prevent the risks of ankle strains in the sporting population.

Sugimoto et al. [33] carried out a meta-analysis that revealed a significant relationship between training programs and proprioception for the prevention of injuries. The statistical analysis showed that proprioceptive training programs helped prevent ankle strains among athletes. In a similar context, Myer et al. [34] focused on the implication of proprioceptive exercises among athletes. The relative outcomes indicated that ankle strains among athletes are extremely common and can be easily prevented through proprioceptive programs. A critical review carried out by Sugimoto et al. [35] also supported the usage of proprioceptive training programs for reducing muscular diseases. Brandon et al. [36] utilized different techniques for assessing the role of proprioceptive exercises. Their study indicated that proprioceptive training programs help reduce strain-related outcomes among athletes.

A limitation of the selected research studies concerns insufficient information about training parameters and substantial variability. For instance, all of the selected research articles indicated that the training programs were divided into different sessions with pre and post techniques. However, the studies failed to provide knowledge about the parameters utilized for measuring ankle problems and their complications. At the same time, the selected research studies also failed to provide relevant information about exercise duration. None of the research studies indicated the specific length of time and number of sessions for the training programs [2,25-28]. Despite this perspective of variability, a proper impact was also detected in this review.

The optimal ratio between dose and response for the prophylactic impact of proprioceptive training programs remains unclear. A cumulative impact may exist; however, longer programs have a direct preventive impact [1]. It is extremely difficult to assess training programs and their effectiveness as far as preventive parameters are concerned. Future studies can develop different training parameters in order to increase safety and quality of life. However, this systematic review has its own strengths. To begin with, this review completely focused on the effectiveness of proprioceptive training programs among athletes. This review did not deviate from the topic or relative variables at any point of the research process. This review selected only five controlled trials for analysis among a diversified range of research articles. Thus, it can be said that the outcomes of this review are reliable comparatively to other research studies.

\section{CONCLUSIONS}

Ankle-related injuries have been identified as a severe muscular condition, which is usually 
characterized by pain and strains. The prevalence rate of ankle-related injuries has increased at a constant rate among athletes across the globe. Therefore, proprioceptive exercises have been analyzed through meta-analyses and systematic reviews. A wide range of previously published literature has indicated that proprioceptive exercises relatively help athletes prevent ankle strains. Moreover, a comparison between the studies selected for the systematic review and previously published literature has identified that proprioceptive exercises are necessary to enhance the quality of life of athletes. Therefore, it can be concluded from the meta-analysis that ankle strains and other injuries can be easily minimized and prevented among athletes through neuromuscular proprioceptive exercise training. However, a larger sample size can be utilized in future studies to identify more comprehensive outcomes related to ankle injuries.

\section{NOTES}

\section{Financial support}

This study did not receive financial support from outside sources.

\section{Conflicts of interest disclosure}

The authors declare no competing interests relevant to the content of this study; they state to have full access to all available data and to take complete responsibility for the integrity of the results.

\section{REFERENCES}

1. Bahr R, Lian O, Bahr IA. A twofold reduction in the incidence of acute ankle sprains in volleyball after the introduction of an injury prevention program: a prospective cohort study. Scand J Med Sci Sports. 1997;7(3):172-7. https://doi. org/10.1111/j.1600-0838.1997.tb00135.x

2. Eils E, Schroter R, Schroder M, Gerss J, Rosenbaum D. Multistation proprioceptive exercise program prevents ankle injuries in basketball. Med Sci Sports Exerc, 2010;42(11):2098-105. https://doi.org/10.1249/MSS.0b013e3181e03667

3. Holm I, Fosdahl MA, Friis A, Risberg MA, Myklebust G, Steen H. Effect of neuromuscular training on proprioception, balance, muscle strength, and lower limb function in female team handball players. Clin J Sport Med, 2004;14(2):88-94. https://doi.org/10.1097/00042752-200403000-00006

4. Imamura M, Imamura ST, Kaziyama HH, Targino RA, Hsing WT, De Souza LPM, Camanho GL. Impact of nervous system hyperalgesia on pain, disability, and quality of life in patients with knee osteoarthritis: a controlled analysis. Arthritis Rheum. 2008 Oct 15;59(10):1424-31. https://doi.org/10.1002/art.24120

5. Seed SM, Dunican KC, Lynch AM. Osteoarthritis: a review of treatment options. Geriatrics. 2009 Oct;64(10):20-9.

6. Kurtz SM, Ong KL, Lau E, Widmer M, Maravic M, Gómez-Barrena E, de Pina Mde F, Manno V, Torre M, Walter WL, de Steiger R, Geesink RG, Peltola M, Röder C. International survey of primary and revision total knee replacement. Int Orthop. 2011 Dec;35(12):1783-9. https://doi.org/10.1007/s00264-011-1235-5

7. Meneghini RM, Russo GS, Lieberman JR. Modern perceptions and expectations regarding total knee arthroplasty. J Knee Surg. 2014 Apr;27(2):93-7.

8. Beswick AD, Wylde V, Gooberman-Hill R, Blom A, Dieppe P. What proportion of patients report long-term pain after total hip or knee replacement for osteoarthritis? A systematic review of prospective studies in unselected patients. BMJ Open. 2012 Feb 22;2(1):e000435. https://doi.org/10.1136/bmjopen-2011-000435

9. Scott CEH, Howie CR, MacDonald D, Biant LC. Predicting dissatisfaction following total knee replacement: a prospective study of 1217 patients. J Bone Joint Surg Br. 2010 Sept;92(9):1253-8. https://doi.org/10.1302/0301-620X.92B9.24394

10. Mancuso CA, Graziano S, Briskie LM, Peterson MG, Pellicci PM, Salvati EA, Sculco TP. Randomized trials to modify patients' preoperative expectations of hip and knee arthroplasties. Clin Orthop, 2008;466(2):424-31. https://doi.org/10.1007/ s11999-007-0052-Z

11. Huber EO, Roos EM, Meichtry A, de Bie RA., Bischoff-Ferrari HA. Effect of preoperative neuromuscular training (NEMEX-TJR) on functional outcome after total knee replacement: an assessor-blinded randomized controlled trial. BMC Musculoskelet Disord. 2015 Apr 25;16:101. https://doi.org/10.1186/s12891-015-0556-8

12. Hewett TE, Paterno MV, Myer GD. Strategies for enhancing proprioception and neuromuscular control of the knee. Clin Orthop Relat Res. 2002 Sept;(402):76-94. https://doi.org/10.1097/00003086-200209000-00008

13. Schiftan GS, Ross LA, Hahne AJ. The effectiveness of proprioceptive training in preventing ankle sprains in sporting populations: A systematic review and meta-analysis. J Sci Med Sport. 2015 May;18(3):238-44. https://doi.org/10.1016/j. jsams.2014.04.005

14. Fong DTP, Hong Y, Chan LK, Yung PSH, Chan KM. A systematic review on ankle injury and ankle sprain in sports. Sports Med. 2007;37(1):73-94. https://doi.org/10.2165/00007256-200737010-00006 
15. Hupperets MD, Verhagen EA, Heymans MW, Bosmans JE, van Tulder MW, van Mechelen W. Potential savings of a program to prevent ankle sprain recurrence economic evaluation of a randomized controlled trial. Am J Sports Med. 2010 Nov;38(11):2194-200. https://doi.org/10.1177/0363546510373470

16. Hiller CE, Nightingale EJ, Raymond J, Kilbreath SL, Burns J, Black DA, Refshauge KM. Prevalence and impact of chronic musculoskeletal ankle disorders in the community. Arch Phys Med Rehabil, 2012;93(10):1801-7. https://doi. org/10.1016/j.apmr.2012.04.023

17. Verhagen EALM, Bay K. Optimising ankle sprain prevention: a critical review and practical appraisal of the literature. Br J Sports Med. 2010;44(15):1082-88. https://doi.org/10.1136/bjsm.2010.076406

18. Van Rijn RM, Van Os AG, Bernsen RM, Luijsterburg PA, Koes BW, Bierma-Zeinstra SM. What is the clinical course of acute ankle sprains? A systematic literature review. Am J Med. 2008 Apr;121(4):324-31. https://doi.org/10.1016/j. amjmed.2007.11.018

19. Raymond J, Nicholson LL, Hiller CE, Refshauge KM. The effect of ankle taping or bracing on proprioception in functional ankle instability: a systematic review and meta-analysis. J Sci Med Sport. 2012 Sept;15(5):386-92. https:// doi.org/10.1016/j.jsams.2012.03.008

20. Hübscher M, Zech A, Pfeifer K, Hänsel F, Vogt L, Banzer W. Neuromuscular training for sports injury prevention: A systematic review. Med Sci Sports Exerc. 2010 Mar;42(3):413-21. https://doi.org/10.1249/MSS.0b013e3181b88d37

21. de Vries JS, Krips R, Sierevelt IN, Blankevoort L, van Dijk CN. Interventions for treating chronic ankle instability. Cochrane Database Syst Rev. 2011 Aug 10;(8):CD004124. https://doi.org/10.1002/14651858.cd004124.pub3

22. Zech A, Hubscher M, Vogt L, Banzer W, Hansel F, Pfeifer KLAUS. Neuromuscular training for rehabilitation of sports injuries: a systematic review. Med Sci Sports Exerc. 2009;41(10):1831-41. https://doi.org/10.1249/MSS.0b013e3181a3cf0d

23. Webster KA, Gribble PA. Functional rehabilitation interventions for chronic ankle instability: a systematic review. J Sport Rehabil. 2010;19(1):98-114. https://doi.org/10.1123/jsr.19.1.98

24. Verhagen E, van der Beek A, Twisk J, Bouter L, Bahr R, van Mechelen W. The effect of a proprioceptive balance board training program for the prevention of ankle sprains: a prospective controlled trial. Am J Sports Med. 2004 Sept;32(6):1385-93. https://doi.org/10.1177/0363546503262177

25. Hupperets MD, Verhagen EA, Van Mechelen W. Effect of unsupervised home based proprioceptive training on recurrences of ankle sprain: randomised controlled trial. BMJ. 2009 Jul 9;339:b2684. https://doi.org/10.1136/bmj.b2684

26. Emery CA, Rose MS, McAllister JR, Meeuwisse WH. A prevention strategy to reduce the incidence of injury in high school basketball: a cluster randomized controlled trial. Clin J Sport Med. 2007;17(1):17-24. https://doi.org/10.1097/ JSM.0b013e31802e9c05

27. Mohammadi F. Comparison of 3 preventive methods to reduce the recurrence of ankle inversion sprains in male soccer players. Am J Sports Med. 2007;35(6):922-26. https://doi.org/10.1177/0363546507299259

28. McGuine TA, Keene JS. The effect of a balance training program on the risk of ankle sprains in high school athletes. Am J Sports Med. 2006;34(7):1103-11. https://doi.org/10.1177/0363546505284191

29. Bazzucchi I, De Vito G, Felici F, Dewhurst S, Sgadari A, Sacchetti M. Effect of exercise training on neuromuscular function of elbow flexors and knee extensors of type 2 diabetic patients. J Electromyogr Kinesiol. 2015 Oct;25(5): 815-23. https://doi.org/10.1016/j.jelekin.2015.06.008

30. Ageberg E, Roos EM. Neuromuscular exercise as treatment of degenerative knee disease. Exerc Sport Sci Rev. 2015 $1 ; 43(1): 14-22$.

31. Villadsen A, Overgaard S, Holsgaard-Larsen A, Christensen R, Roos EM. Postoperative effects of neuromuscular exercise prior to hip or knee arthroplasty: a randomised controlled trial. Ann Rheum Dis. 2014 June 1;73(6):1130-7. https://doi. org/10.1136/annrheumdis-2012-203135

32. Ergen E, Ulkar B. Proprioception and ankle injuries in soccer. Clin Sports Med. 2008;27(1):195-217. https://doi. org/10.1016/j.csm.2007.10.002

33. Sugimoto D, Myer GD, Foss KD, Hewett TE. Specific exercise effects of preventive neuromuscular training intervention on anterior cruciate ligament injury risk reduction in young females: meta-analysis and subgroup analysis. Br J Sports Med. 2015;49(5):282-9.

34. Myer GD, Sugimoto D, Thomas S, Hewett TE. The influence of age on the effectiveness of neuromuscular training to reduce anterior cruciate ligament injury in female athletes a meta-analysis. Am J Sports Med. 2013 Jan;41(1):203-15. https://doi.org/10.1177/0363546512460637

35. Sugimoto D, Myer GD, McKeon JM, Hewett TE. Evaluation of the effectiveness of neuromuscular training to reduce anterior cruciate ligament injury in female athletes: a critical review of relative risk reduction and numbers-needed-totreat analyses. Br J Sports Med. 2012 Nov 1;46(14):979-88. https://doi.org/10.1136/bjsports-2011-090895

36. Brandon R, Howatson G, Strachan F, Hunter AM. Neuromuscular response differences to power vs strength back squat exercise in elite athletes. Scand J Med Sci Sports. 2015;25(5):630-9. https://doi.org/10.1111/sms.12289

37. Creswell JW. Research design: qualitative, quantitative, and mixed methods approaches. Lincoln: Sage publications; 2013. 